\title{
FIRST RECORD OF A SINGLE-CLASPER SPECIMEN OF PSEUDOBATOS PERCELLENS (ELASMOBRANCHII: RHINOPRISTIFORMES: RHINOBATIDAE) FROM THE CARIBBEAN SEA, VENEZUELA
}

\author{
Nicolás R. EHEMANN ${ }^{1,2,3^{*}}$ and Lorem del V. GONZÁLEZ-GONZÁLEZ ${ }^{1}$ \\ ${ }^{1}$ Instituto Politécnico Nacional, Centro Interdisciplinario de Ciencias Marinas, La Paz, México \\ ${ }^{2}$ Universidad de Oriente, Escuela de Ciencias aplicadas del Mar, Nueva Esparta, Venezuela \\ ${ }^{3}$ Proyecto Iniciativa Batoideos (PROVITA) Caracas, Venezuela
}

\begin{abstract}
Ehemann N., González-González L. 2018. First record of a single-clasper specimen of Pseudobatos percellens (Elasmobranchii: Rhinopristiformes: Rhinobatidae) from the Caribbean Sea, Venezuela. Acta Ichthyol. Piscat. 48 (3): 235-240.

Abstract. Documented cases of abnormalities in elasmobranchs worldwide are more often reported for sharks than their close relatives, the skates and rays. This report confirms the occurrence of a chola guitarfish, Pseudobatos percellens (Walbaum, 1792), caught off Margarita Island, Venezuela, showing morphological abnormalities on the right side of the body, including the absence of one clasper. This is the first record of an anomalous singleclasper case in the Caribbean Sea region.
\end{abstract}

Keywords: batoid fish, Chondrichthyes, deformity, guitarfish, reproduction

\section{INTRODUCTION}

Documented cases of abnormalities in elasmobranchs worldwide are most often reported for sharks (Atz 1964, Heupel et al. 1999, Teixeira and Góes de Araújo 2002, Jones et al. 2005, Saïdi et al. 2006, Bottaro et al. 2009, Delpiani et al. 2011, Galván-Magaña et al. 2011, Muñoz-Osorio et al. 2013, Wagner et al. 2013, Ehemann et al. 2016, BecerrilGarcía et al. 2017, Lamarca et al. 2017, Capapé and Ali 2017) and rarely for skates and rays. Nevertheless, the number of records of anomalous defects in batoid fish specimens have increased over the past decade, including morphological anomalies (Escobar-Sánchez et al. 2009, Mejía-Falla et al. 2011, Ramírez-Hernández et al. 2011, Torres-Huerta et al. 2015), albinism (Sandoval-Castillo et al. 2006, Ben-Souissi et al. 2007, Ball et al. 2013), and dicephalic embryos (CastroAguirre and Torres-Villegas 1979, Bornatowski and Abilhoa 2009, Guida et al. 2014). Cases of hermaphroditism (Gianeti and Vooren 2007, Scenna et al. 2007, Haas and Ebert 2008, Ribeiro-Prado et al. 2009, Capapé et al. 2012, Rafrafi-Nouira et al. 2017) and more recently, cases of parthenogenesis birth (Fields et al. 2015, Harmon et al. 2015) were also reported.

Cases documenting the presence of a single clasper in batoid fishes specimens are scarce, with only five known worldwide: a Tunisian Raja miraletus Linnaeus, 1758; two Brazilian specimens, a Pteroplatytrygon violacea (Bonaparte, 1832); an Urotrygon microphthalmum Delsman, 1941; and other two distinct individuals captured in the west coast of
Mexico, Urotrygon chilensis (Günther, 1872) and a Zapteryx exasperata (Jordan et Gilbert, 1880) (see Quignard and Capapé 1972, Ribeiro-Prado et al. 2009, Santander-Neto and Lessa 2013, Torres-Huerta et al. 2015, González-González et al. 2016).

An anomalous embryo of Pseudobatos percellens (Walbaum, 1792) was recorded in southern Brazil (Bornatowski and Abilhoa 2009) documenting the first occurrence of a malformation for this species. The specimen was a two-headed embryo with pectoral fins separated from the head. It was suggested that this individual was potentially associated with poor nutrition during the gestation period, however, genetic and environmental causes remain an alternative hypothesis. Pseudobatos percellens, is a shallow-water species with a distribution range stretching from Panamá to Brazil, including the Lesser Antilles (Cervigón and Alcalá 1999, Last et al. 2016). The aim of the presently reported study was to record and describe the first case of a chola guitarfish ( $P$. percellens) from the Caribbean Sea with single clasper and morphological abnormalities.

\section{MATERIAL AND METHODS}

On 5 November 2013, a chola guitarfish individual (Fig. 1A, B) was captured by a local fisherman using a bottom trawling net in La Pared beach (landing coordinates $\left.11^{\circ} 03^{\prime} 33^{\prime \prime} \mathrm{N} 64^{\circ} 18^{\prime} 46^{\prime \prime} \mathrm{W}\right)$, Margarita Island, Venezuela 
located in the south-eastern part of the Caribbean Sea. The identification of the specimen to species level was made based on Cervigón and Alcalá (1999), McEachran and Carvalho (2002), and Last et al. (2016). Morphological measurements (i.e., disc width, total length (TL), clasper length, pelvic fin length and width) of the specimen were recorded using a digital calliper to the nearest $0.01 \mathrm{~mm}$ according to Last et al. (2008). The calcification state and the degree of rotation of the clasper were used to determine sexual maturity (immature or mature) according to Conrath (2004). An X-ray plate (Fig. 1C) and a ventral dissection of the specimen (Fig. 2) were performed, to examine the presence of a vestigial internal structure of the missing clasper and also for the meristic information of both pelvic fins.

A morphometric comparison was made between this specimen and a normal male caught at the same locality with similar measures ( $\mathrm{TL}=557 \mathrm{~mm}$ weighing $530 \mathrm{~g}$ ) (Table 1). The single-clasper specimen was donated, deposited and exhibited at the Museo Marino de Margarita, Venezuela (catalogue number MMM 1929).

\section{RESULTS}

The specimen was differentiated from the other western Atlantic Pseudobatos species-i.e., Pseudobatos lentiginosus (Garman, 1880) and Pseudobatos horkelii (Müller et Henle, 1841) - by its striking pattern of white spots on the dorsal (Fig. 1B), much less numerous and larger than those of the freckled guitarfish, Pseudobatos lentiginosus. Meanwhile the Brazilian guitarfish ( $P$. horkelii) is thought to be the only plain-coloured Pseudobatos in the western Atlantic. According to Last et al. (2016) the geographic distribution data of the three species were also valuable because those guitarfish species are not sympatric. Pseudobatos lentiginosus is restricted to the Gulf of Mexico, P. percellens is only present in the waters stretching from the Caribbean Sea to northern Brazil and P. horkelii inhabits the coastal shelf from southern Brazil to Argentina.

The total length (TL) of the anomalous specimen was $558 \mathrm{~mm}$ and its weight $500 \mathrm{~g}$. Overall, the individual appeared to be a normal guitarfish, based on an external examination (Fig. 1A, B), and classified as a mature
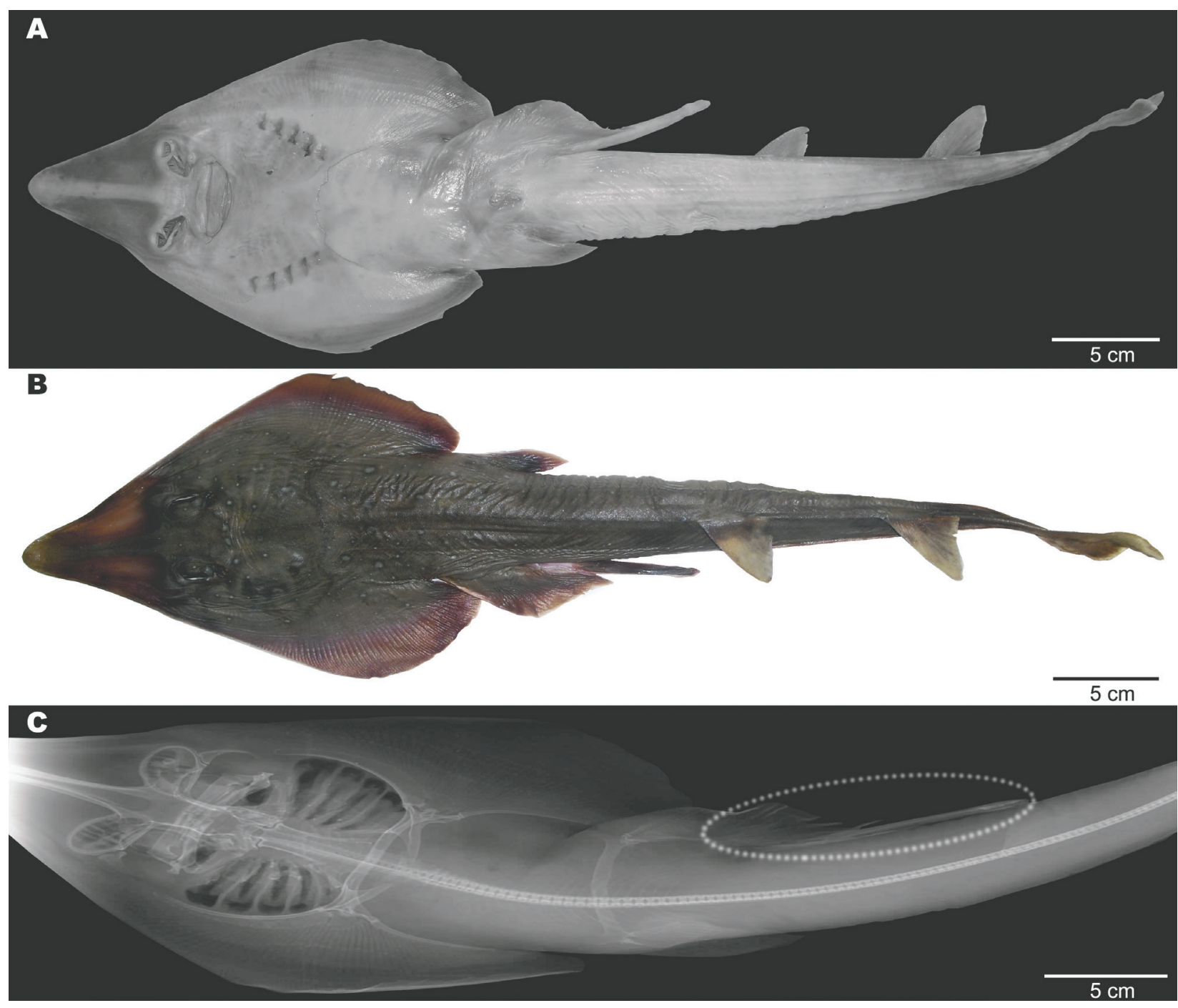

Fig. 1. External view of the Pseudobatos percellens caught off the Margarita Island, Venezuela (No. MMM 1929); ventral view (A), dorsal view $(\mathbf{B})$, and the $\mathrm{X}$ ray plate $(\mathbf{C})$; the elliptic zone describe the location of the single clasper 
male based on the stage of the development of the single clasper, and the mean size of sexual maturity for males $\left(L_{50}=520 \mathrm{~mm}\right.$ TL) estimated by Tagliafico et al. (2013) for $P$. percellens at the same locality (La Pared Beach). The length of the single clasper was $94.65 \mathrm{~mm}$ representing $17 \%$ of the total length. An abnormality on the right pelvic fin was recorded to be smaller than the left side. The difference of approximately 30 percentage points (pp) resulted from the left side $(13.25 \mathrm{~mm})$ to be longer and by $46.4 \mathrm{pp}(14.46 \mathrm{~mm})$ wider than the right side (Table 1).

\section{DISCUSSION}

The results obtained from an external examination (Fig 1A), via X-ray plate (Fig. 1C), combined with a ventral dissection (Fig. 2) revealed the lack of scars, the absence of vestigial or residual development of this anatomical structure on the out and the inner side of the

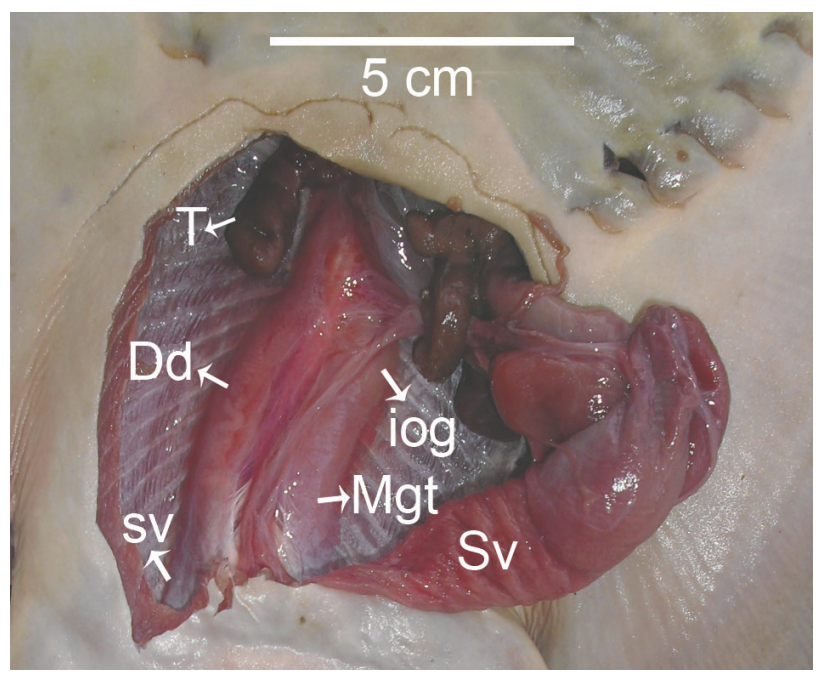

Fig. 2. Internal organs and reproductive system of the single-clasper Pseudobatos percellens specimen caught on the Margarita Island, Venezuela (No. MMM 1929); $\mathrm{Dd}=$ ductus deferens, iov $=$ inconspicuous oviductal gland, Mgt = membranous genital tract, $\mathrm{S}=$ stomach, $\mathrm{Sv}=$ spiral valve, $\mathrm{sv}=$ seminal vesicle, $\mathrm{T}=$ testis chola guitarfish, refuting the hypothesis of predation or amputation, as has been previously reported for Leucoraja circularis (Couch, 1838) and Bathyraja richardsoni (Garrick, 1961) (see Mnasri et al. 2009, Orlov 2011).

The absence of one clasper has repercussions during reproduction, even though when an elasmobranch male must insert one of the claspers during copulation (Carrier et al. 1994, Chapman et al. 2003). The lack of a clasper potentially reduces the success of the reproduction process of the single-clasper specimens (Torres-Huerta et al. 2015). The missing clasper of the six cases (including this study) reported with this anomaly, seems to be random, given that, three cases correspond to the absence of the left clasper (two of them belongs to Myliobatiformes species). However, the other three remaining cases (opposite clasper) two of them correspond to Rhinopristiformes species and one to the Myliobatiformes. This "fortuity", may represent the possibility of consistency on the missing clasper side at higher taxonomy levels such as Order (at least for Rhinopristiformes and Rajiformes). Nevertheless, more cases and studies must be done to support this hypothesis.

According to Atz (1964) and Irvine et al. (2002), elasmobranchs may have two types of hermaphroditism referred to as "true or normal" and/or "pseudo or abnormal". The main characteristic of the first group is the internal presence of organs of both sexes, and the external presence of claspers. In this case, a mature individual could function as both male and female. In comparison, the other group possesses the internal sex organs of one gender and externally the sex organs of the other gender (Irvine et al. 2002). Both cases of hermaphroditism have been previously recorded for different batoid species (Capapé et al. 2012, Rafrafi-Nouira et al. 2017). The anatomical dissection of this chola guitarfish, showed one side with macroscopic male organs (i.e., testis, ductus deferens, and seminal vesicle) and the other side, with what appears to be an inconspicuous oviducal gland and a membranous genital tract (Fig. 2).

The confirmation using a histological technique for the "female organs" could not be done, due to the conditions

Table 1

Weight and morphometric information of the single-clasper specimen and a normal male of Pseudobatos percellens caught off the Margarita Island, Venezuela (No. MMM 1929);

\begin{tabular}{|c|c|c|c|c|c|c|c|c|}
\hline \multirow{3}{*}{ Character } & \multicolumn{4}{|c|}{ Single-clasper specimen } & \multicolumn{4}{|c|}{ Normal male specimen } \\
\hline & \multicolumn{2}{|c|}{ Right } & \multicolumn{2}{|c|}{ Left } & \multicolumn{2}{|c|}{ Right } & \multicolumn{2}{|c|}{ Left } \\
\hline & AV & $\% \mathrm{TL}$ & AV & $\% \mathrm{TL}$ & $\mathrm{AV}$ & $\% \mathrm{TL}$ & AV & $\% \mathrm{TL}$ \\
\hline Total weight $[\mathrm{g}]$ & \multicolumn{4}{|c|}{500} & \multicolumn{4}{|c|}{530} \\
\hline Total length [mm] & \multicolumn{4}{|c|}{558} & \multicolumn{4}{|c|}{557} \\
\hline Disc width [mm] & \multicolumn{4}{|c|}{178} & \multicolumn{4}{|c|}{179} \\
\hline Clasper length $[\mathrm{mm}]$ & 94.65 & 17.0 & - & - & 93.50 & 16.8 & 93.75 & 16.8 \\
\hline Pelvic fin length [mm] & 44.40 & 8.0 & 31.15 & 5.6 & 43.80 & 7.9 & 43.95 & 7.9 \\
\hline Pelvic fin length [mm] & 31.15 & 5.6 & 16.70 & 3.0 & 30.95 & 5.5 & 31.00 & 5.6 \\
\hline No of soft-ray pelvic fin & \multicolumn{2}{|c|}{22} & \multicolumn{2}{|c|}{14} & \multicolumn{2}{|c|}{ - } & \multicolumn{2}{|c|}{ - } \\
\hline
\end{tabular}

$\mathrm{AV}=$ absolute value $[\mathrm{mm}], \% \mathrm{TL}=$ relative value expressed in percent of the total length. 
of the specimen as a result of poor preservation. The possibility to be in the presence of a true hermaphroditism specimen are not rejected, if this inference were true, it would be the second case (among the six single-clasper individuals cases), with a true hermaphroditism, along with Raja miraletus Linnaeus, 1758 (see Quignard and Capapé 1972) which may be considered as true hermaphroditism due to the presence of both sex organs.

The causes of these reproductive abnormalities (with a single clasper) remain uncertain and inconclusive, however, the most probable hypothesis is related to the embryonic development from an endogenous origin (e.g., genetic, hormonal), among others as in other vertebrates (Ribeiro-Prado et al. 2009). Causes such as consanguinity within the population (Santander-Neto and Lessa 2013), radioactive contamination (Yano and Tanaka 1989), environmental degradation, pollution, and chemical particulates such as those from the use of dichlorodiphenyltrichloroethane (DDT) (Torres-Huerta et al. 2015) cannot be denied. However, there is no conclusive evidence that may corroborate these hypotheses in the study area, even though these contaminants can be accumulated in the marine substrate, and benthic species such as Pseudobatos percellens are susceptible. Further investigation must be done to clarify the causes of this kind of abnormalities in this group of fishes.

\section{ACKNOWLEDGEMENTS}

The authors are thankful to the fisherman of Playa La Pared, for sharing the specimen and to the Museo Marino de Margarita for space and help provided in the examination of this Pseudobatos percellens. Thanks are extended to Stephanie Rousso and Kathryn Ayres for their help in the English manuscript. Both authors thanks CONACyT (Consejo Nacional de Ciencia y Tecnología) and the BEIFI-IPN for the scholarships provided.

\section{REFERENCES}

Atz J.W. 1964. Intersexuality in fishes. Pp. 145-232. In: Armstrong C.N., Marshall AJ. (eds.) Intersexuality in vertebrates including man. Academic Press, London, UK.

Ball R.E., Jones C.S., Lynghammar A., Noble L.R., Griffiths A.M. 2013. The first confirmed cases of full albinism in rajid species. Journal of Fish Biology 82 (4): 1433-1440. DOI: 10.1111/jfb.12072

Becerril-García E.E., Tamburin E., González-Armas R., Galván-Magaña F. 2017. First record of albinism in the swell shark, Cephaloscyllium ventriosum (Elasmobranchii: Carcharhiniformes: Scyliorhinidae). Acta Ichthyologica et Piscatoria 47 (2): 201-204. DOI: 10.3750/AIEP/02175

Ben-Souissi J., Golani D., Méjri H., Ben-Salem M., Capapé C. 2007. First confirmed record of the Halave's guitarfish, Rhinobatos halavi (Forsskål, 1775) (Chondrichthyes: Rhinobatidae) in the Mediterranean Sea whit a description of a case of albinism in elasmobranchs. Cahiers de Biologie Marine 48 (1): 67-75. DOI: 10.21411/CBM.A.9AA3ED77
Bornatowski H., Abilhoa V. 2009. Record of an anomalous embryo of Rhinobatos percellens (Elasmobranchii: Rhinobatidae) in the southern coast of Brazil. Marine Biodiversity Records 2: e36. DOI: 10.1017/S1755267209000414

Bottaro M., Ferrando S., Gallus L., Girosi L., Vacchi M. 2009. First record of albinism in the deep-water shark Dalatias licha. Marine Biodiversity Records 1: e10. DOI: $10.1017 / \mathrm{S} 1755267205001156$

Capapé C., Ali M. 2017. Record of dicephalous embryo in longnose spurdog Squalus blainvillei (Chondrichthyes: Squalidae) from the Syrian coast (eastern Mediterranean). Annales Series Historia Naturalis 27 (1): 59-62. DOI: 10.19233/ASHN.2017.08

Capapé C., El Kamel-Moutalibi O., Mnasri N., Boumaïza M., Reynaud C. 2012. A case of hermaphroditism in Tortonese's stingray, Dasyatis tortonesei(Elasmobranchii: Rajiformes: Dasyatidae) from the Lagoon of Bizerte, Tunisia. Acta Ichthyologica et Piscatoria 42 (2): 141149. DOI: 10.3750/AIP2011.42.2.08

Carrier J.C., Pratt H.L.jr., Martin L.K. 1994. Group reproductive behaviors in free-living nurse sharks, Ginglymostoma cirratum. Copeia 1994 (3): 646-656. DOI: $10.2307 / 1447180$

Castro-Aguirre J.L., Torres-Villegas J.R 1979. Sobre un caso de bicefalia funcional en Rhinoptera steindachneri Evermann y Jenkins (Chondrichthyes, Elasmobranchii, Batoidei) capturado en la Costa Occidental de Baja California Sur, México. Ciencias Marinas 6 (1): 27-41. DOI: 10.7773/cm.v6i1.351

Cervigón F., Alcalá A. 1999. Los peces marinos de Venezuela. Vol. V. Fundación Museo del Mar, Caracas, Venezuela.

Chapman D.D., Corcoran M.J., Harvey G.M., Malan S., Shivji M.S. 2003. Mating behavior of southern stingrays, Dasyatis americana (Dasyatidae). Environmental Biology of Fishes 68 (3): 241-245. DOI: 10.1023/A:1027332113894

Conrath C. 2004. Reproductive biology. Pp. 133-164. In: Musick J., Bonfil R. (eds.) Elasmobranch fisheries management techniques. APEC Secretariat, Singapore.

Delpiani S.M., Deli Antoni M.Y., Barbini S.A., Figueroa D.E. 2011. First record of a dicephalic specimen of tope Galeorhinus galeus (Elasmobranchii: Triakidae). Journal of Fish Biology 78 (3): 941-944. DOI: 10.1111/j.1095-8649.2010.02890.x

Ehemann N.R., Marín-Sanz J., Barany-González M. 2016. Two cases of two-head shark embryos, smalleye smooth-hound Mustelus higmani and the blue shark Prionace glauca. Instituto de Investigaciones Marinas y Costeras 45 (1): 149-153. DOI: 10.25268/bimc. invemar.2016.45.1.636

Escobar-Sánchez O., Galván-Magaña F., DowntonHoffmann C.A., Carrera-Fernández M., AlatorreRamírez V.G. 2009. First record of a morphological abnormality in the longtail stingray Dasyatis longa (Myliobatiformes: Dasyatidae) in the Gulf of California, Mexico. Marine Biodiversity Records 2: e26. DOI: $10.1017 /$ S1755267208000304 
Fields A.T., Feldheim K.A., Poulakis G.R., Chapman D.D. 2015. Facultative parthenogenesis in a critically endangered wild vertebrate. Current Biology 25 (11): R446-R447. DOI: 10.1016/j.cub.2015.04.018

Galván-Magaña F., Escobar-Sánchez O., CarreraFernández M. 2011. Embryonic bicephaly in the blue shark, Prionace glauca, from the Mexican Pacific Ocean. Marine Biodiversity Records 4: e1. DOI: $10.1017 / \mathrm{S} 1755267210001120$

Gianeti M.D., Vooren C.M. 2007. A hermaphrodite guitarfish, Rhinobatos horkelii (Müller \& Henle, 1841) (Rajiformes: Rhinobatidae), from southern Brazil. Cahiers de Biologie Marine 48 (4): 407-409. DOI: 10.21411/CBM.A.5E8510EA

González-González L.V., Burgos-Vásquez M.I., Mejía-Falla P.A., Cruz-Escalona V.H. 2016. Primer reporte de mono clasper en Zapteryx exasperata (Rhinopristiformes: Trygonorrninidae) para el Golfo de California, México. Pp. 213-214. In: Compendio de resúmenes orales y carteles del XV Congreso Nacional de Ictiología, V Simposio Latinoamericano de Ictiología, I Simposio Internacional de Genómica de Peces. Aguascalientes, México. DOI: 10.13140/ RG.2.2.22653.77284

Guida L., Walker T.I., Reina R.D. 2014. First record of a bicephalic chondrichthyan found in Australian waters; the southern fiddler ray, Trygonorrhina dumerilii (Chondrichthyes: Rhinobatidae). Marine and Freshwater Research 65 (5): 396-399. DOI: 10.1071/MF13198

Haas D.L., Ebert D.A. 2008. First record of hermaphroditism in the Bering skate, Bathyraja interrupta. Northwestern Naturalist 89 (3): 181-185. DOI: $10.1898 / \mathrm{NWN} 07-23.1$

Harmon T.S., Kamerman T.Y., Corwin A.L., Sellas A.B. 2015. Consecutive parthenogenetic births in a spotted eagle ray Aetobatus narinari. Journal of Fish Biology 88 (2): 1095-8649. DOI: 10.1111/jfb.12819

Heupel M.R., Simpfendorfer C.A., Bennett M.B. 1999. Skeletal deformities in elasmobranchs from Australian waters. Journal of Fish Biology 54 (5): 1111-1115. DOI: 10.1111/j.1095-8649.1999.tb00861.X

Irvine S.B., Laurenson L.J., Stevens J.D. 2002. Hermaphroditism in the southern lantern shark, Etmopterus granulosus. Pp. 49-54. In: Martin R.A., MacKinlay (eds.) Biology of deep sea elasmobranchs. Symposium proceedings. International Congress on the Biology of Fish, 22-25 July 2002, Vancouver, Canada.

Jones A.A., White W.T., Potter I.C. 2005. A hermaphroditic Port Jackson shark, Heterodontus portusjacksoni, with complete and separate female and male reproductive tracts. Journal of the Marine Biological Association of the United Kingdom 85 (5): 1171-1172. DOI: $10.1017 / \mathrm{S} 0025315405012269$

Lamarca F., Ribeiro N., Galheigo F., Vianna M. 2017. The first record of diprosopus tetrophthalmus in the South Atlantic Ocean: The case of Prionace glauca (Elasmobranchii: Carcharhiniformes: Carcharhinidae) in Brazil. Acta Ichthyologica et Piscatoria 47 (4): 385389. DOI: $10.3750 / \mathrm{AIEP} / 02226$
Last P.R., White W.T., Pogonoski J.J., Gledhill D.C. 2008. New Australian skates (Batoidea: Rajoidei) background and methodology. Pp. 1-9. In: Last P.R, White W.T., Pogonoski J.J., Gledhill, D.C. (eds.) Description of new Australian Skates (Batoidea: Rajoidei). CSIRO Marine and Atmospheric Research Paper No. 021, CSIRO, Hobart, TAS, Australia.

Last P.R., White W.T., de Carvalho M.R., Séret B., Stehmann F.W., Naylor G.J.P. 2016. Rays of the world. Cornell University Press, Ithaca, NY, USA.

McEachran J.D., Carvalho M.R. 2002. Rhinobatidae. Pp. 527-530. In: Carpenter K.E. (ed.) The living marine resources of the western central Atlantic. Vol. 1. FAO Species Identification Guide for Fishery Purposes. FAO, Rome.

Mejía-Falla P.A., Navia A.F., Muñoz L.A. 2011. First record of morphological abnormality in embryos of Urotrygon rogersi (Jordan \& Starks, 1895) (Myliobatiformes: Urotrygonidae) in the Tropical Eastern Pacific. Latin American Journal of Aquatic Research 39 (1): 184-188. DOI: 10.3856/vol39issue1-fulltext-19

Mnasri N., Boumaïza M., Capapé C. 2009. Morphological data, biological observations and occurrence of a rare skate, Leucoraja circularis (Chondrichthyes: Rajidae), off the northern coast of Tunisia (central Mediterranean). Pan-American Journal of Aquatic Sciences 4 (1): 70-78.

Muñoz-Osorio L.A., Mejía-Falla P.A., Navia A.F. 2013. First record of a bicephalic embryo of smalltail shark Carcharhinus porosus. Journal of Fish Biology 82 (5): 1-5. DOI: $10.1111 / \mathrm{jfb} .12102$

Orlov A.M. 2011. Record of a tailless Richardson's ray Bathyraja richardsoni (Garrick, 1961) (Rajiformes: Arhynchobatidae) caught off the Mid-Atlantic Ridge. PanAmerican Journal of Aquatic Sciences 6 (3): 232-236.

Quignard J.P., Capapé C. 1972. Cas d'hermaphrodisme chez Raja miraletus L. 1758. Travaux du laboratoire de biologie halieutique 6: 133-140.

Rafrafi-Nouira S., El Kamel-Moutalibi O., Ounifi-Ben Amor K., Ben Amor M.M., Capapé C. 2017. A case of hermaphroditism in the common eagle ray Myliobatis aquila (Chondrichthyes: Myliobatidae), reported from the Tunisian coast (central Mediterranean). Annales Series Historia Naturalis 27 (1): 43-48. DOI: 10.19233/ASHN.2017.06

Ramírez-Hernández A., Palacios-Barreto P., GaitánEspitia J.D., Reyes F., Ramírez J. 2011. Morphological abnormality in the longnose stingray Dasyatis guttata (Myliobatiformes: Dasyatidae) in the Colombian Caribbean. Cybium 35 (1): 79-80.

Ribeiro-Prado C.C., Oddone M.C., Amorim A.F., Capapé C. 2009. An abnormal hermaphrodite pelagic stingray Pteroplatytrygon violacea (Dasyatidae) captured off the southern coast of Brazil. Cahiers de Biologie Marine 50 (1): 91-96. DOI: 10.21411/ CBM.A.A486D4DA

Ribeiro-Prado C.C., Oddone M.C., González M.M.B., Amorim A.F., Capapé C. 2008. Morphological 
abnormalities in skates and rays (Chondrichthyes) from southeastern Brazil. Arquivos de Ciencia do Mar 41 (2): 21-28. DOI: 10.21411/CBM.A.A486D4DA

Saïdi B., Bradaï M.N., Marouani S., Guélorget O., Capapé C. 2006. Atypical characteristics of an albino embryo of Carcharhinus plumbeus (Chondrichthyes : Carcharhinidae) from the Gulf of Gabès (southern Tunisia, central Mediterranean). Acta Adriatica 47 (2): 167-174.

Sandoval-Castillo J., Mariano-Meléndez E., VillavicencioGarayzar C. 2006. New records of albinism in two elasmobranchs: The tiger shark Galeocerdo cuvier and the giant electric ray Narcine entemedor. Cybium 30 (2): 191-192.

Santander-Neto J., Lessa R. 2013. Hermaphroditic smalleyed roundray (Urotrygon microphthalmum) from north-eastern Brazil. Marine Biodiversity Records 6: e60. DOI: 10.1017/S1755267213000353

Scenna L.B., Díaz de Astarloa J.M., Cousseau M.B. 2007. Abnormal hermaphroditism in the multispine skate Bathyraja multispinis (Chondrichthyes, Rajidae). Journal of Fish Biology 71 (4): 1232-1237. DOI: $10.1111 / \mathrm{j} .1095-8649.2007 .01586 . x$

Tagliafico A., Rago N., Rangel S.M. 2013. Pesquería y biología de Rhinobatos percellens (Rajiformes:
Rhinobatidae) capturados por la pesquería artesanal de playa La Pared, Venezuela. Revista de Biología Tropical 61 (1): 149-160. DOI: 10.15517/rbt. v61i1.10939

Teixeira S.F., Góes de Araújo M.L. 2002. First record of albinism in the smooth dogfish Mustelus schimitti Springer, 1939 (Carcharhiniformes-Triakidae) from Southern Brazil. Brazilian Archives of Biology and Technology 45 (2): 241-243. DOI: 10.1590/S151689132002000200017

Torres-Huerta A.M., Meraz J., Carrasco-Bautista P.E., Díaz-Carballido P.L. 2015. Morphological abnormalities of round rays of the genus Urotrygon in the Gulf of Tehuantepec. Marine Biodiversity 46 (1): 309-315. DOI: 10.1007/s12526-015-0347-3

Wagner C.M., Rice P.H., Pease A.P. 2013. First record of dicephalia in a bull shark Carcharhinus leucas (Chondrichthyes: Carcharhinidae) foetus from the Gulf of Mexico, U.S.A. Journal of Fish Biology 82 (4): 1419-1422. DOI: 10.1111/jfb.12064

Yano K., Tanaka S. 1989. Hermaphroditism in the lantern shark Etmopterus unicolor (Squalidae, Chondrichthyes). Japanese Journal of Ichthyology 36 (3): 338-345. DOI: 10.1007/BF02905618

Received: 10 November 2017 Accepted: 3 April 2018 Published electronically: 30 September 2018 